\title{
PROBLEM BASED LEARNING (PBL) UNTUK MENINGKATKAN KEMAMPUAN MATEMATIKA SISWA
}

\author{
Aulia Firdaus ${ }^{1}$, Mohammad Asikin ${ }^{1}$, Budi Waluya ${ }^{1}$, Zaenuri ${ }^{1}$ \\ ${ }^{1}$ Universitas Negeri Semarang \\ *Corresponding email: auliafirdaus0124@ students.unnes.ac.id
}

Naskah diterima: 16 Juli 2021| Disetujui: 13 Agustus2021 | Diterbitkan: 15 Agustus 2021

\begin{abstract}
Mathematical literacy ability is the ability to apply, use and interpret mathematics in various contexts such as the ability to reason systematically, use concepts, procedures, and facts to describe or explain by predicting a phenomenon. Literacy ability is an ability that is needed by students to solve problems in real life. Therefore, it is necessary to conduct research in developing and improving students' mathematical literacy skills. The purpose of this study was to conduct a literature study related to the use of PBL to improve students' mathematical literacy skills. This research method is SLR (Systematic Literature Review). Data collection is done by documenting various articles that are related to this research study. In the study there were 20 articles from accredited national journals from sinta 1 to sinta 4 through a search process on google schoolar. Based on the results of the study, it was found that PBL can improve students' mathematical literacy skills. based on the literature study that has been carried out that the PBL learning model can be developed or improved in learning mathematics at both the SMP/MTS and SMA/MA levels.
\end{abstract}

Keywords: Problem Based Learning, Mathematical Literacy, SLR

\begin{abstract}
Abstrak: Kemampuan literasi matematika adalah kemampuan untuk menerapkan, menggunakan, dan menginterpretasikan matematika ke dalam berbagai konteks seperti kemampuan untuk bernalar secara sistematis, menggunakan konsep, prosedur, dan fakta dalam mendeskripsikan atau menjelaskan dengan memprediksi sebuah fenomena. Kemampuan literasi merupakan salah satu kemampuan yang sangat dibutuhkan oleh siswa untuk menyelesaikan persoalan dalam kehidupan nyata. Oleh sebab itu, perlu dilakukan penelitian dalam mengembangkan dan meningkatkan kemampuan literasi matematika siswa. Tujuan dari penelitian ini adalah melakukan studi literature berkaitan dengan penggunaan PBL untuk meningkatkan kemampuan literasi matematika siswa. Metode penelitian ini adalah SLR (Systematic Literature Review). Pengumpulan data dilakukan dengan cara mendokumentasikan berbagai artikel yang memiliki keterkaitan pada kajian penelitian. Dalam penelitian ini terdapat 20 artikel dari jurnal nasional yang terakreditasi dari sinta 1 hingga sinta 5 melalui proses pencarian di google schoolar. Berdasarkan pada hasil penelitian menunjukkan bahwa PBL dapat meningkatkan kemampuan literasi matematika siswa. Berdasarkan studi literature yang telah dilakukan juga menunjukkan model pembelajaran PBL dapat dikembangkan maupun ditingkatkan dalam pembelajaran matematika baik pada jenjang SMP/ MTS dan SMA/ MA.
\end{abstract}

Kata kunci: Problem Based Learning, Literasi Matematika, SLR 


\section{PENDAHULUAN}

Salah satu tantangan yang dihadapi warga Indonesia pada era reformasi abad 21 adalah melesatnya dampak globalisasi, di mana globalisasi berpengaruh pada berbagai aspek kehidupan masayarakat. Kemampuan dasar yang dimiliki siswa seperti membaca, menulis, dan berhitung tidak lagi cukup dimiliki untuk mampu berkompentesi di abad 21 yang penuh dengan tantangan (Nahdi, 2019). Oleh karena itu, pendidikan pada abad 21 harus mampu menyiapkan dan membekali siswa dalam bersaing pada masyarakat global. Sebagaimana (Humsona \& Yuliani, 2018) mengungkapkan bahwa tidak bisa ditolak jika setiap orang yang hidup di era reformasi abad 21 dituntut untuk memiliki empat keterampilan seperti keterampilan berpikir kritis, keterampilan berpikir kreatif, keterampilan komunikasi dan keterampilan kolaborasi.

Sebagaimana Kemendikbud dalam kurikulum saat ini telah menyusun paradigma pembelajaran abad 21 untuk menekankan siswa dengan mencari asal-usul segala informasi yang mereka dapatkan dari berbagai sumber, mampu merumuskan permasalahan, berpikir analitis, mampu bekerjasama dalam kelompok, serta mampu berkolaborasi dalam memecahkan dan menyelsaikan masalah (Wijaya et al., 2016). Oleh karena itu, orientasi pendidikan sekarang ini adalah agar siswa dapat memperoleh empat keterampilan yang dibutuhkan untuk memenuhi kebutuhan masyarakat seperti sekarang ini. Sehingga dengan adanya pendidikan yang dirancang mengikuti kurikulum 2013 diharapkan siswa mampu mengembangkan kemampuan berpikir kritis, kreatif, fleksibel, memecahkan masalah, keterampilan kolaborasi dan inovatif yang diperlukan siswa untuk sukses dalam pekerjaan maupun kehidupan sehari-hari (Astuti, 2018). Sejalan dengan itu, maka kemampuan literasi matematika sangat dibutuhkan sehingga mampu menggunakan pikirannya untuk menyelesaikan dan memecahkan masalah dalam kehidupan sehari-hari dan lebih siap untuk menghadapi tantangan kehidupan mendatang (Stacey \& Turner, n.d.)

Menurut (Ojose, 2011) kemampuan literasi merupakan kemampuan untuk memahami dasar matematika dan menerapkannya dalam kehidupan sehari-hari. Kemampuan literasi matematika menjadi sangat penting bagi siswa karena dapat membantu siswa untuk selalu berpikir sistematis, memahami aturan yang dapat menjadikan matematika sebagai pedoman untuk memecahkan masalah dalam keidupan sehari-hari, dan mampu untuk menerapkan matematika ke dalam disiplin ilmu lain sehingga dapat menyiapkan diri untuk mampu bermasayarakat (Wardono \& Mariani, 2018).

Namun pada kenyataannya kemampuan siswa dalam hal literasi matematika masih tergolong rendah dibandingkan dengan negara lain. Hal itu ditunjukkan dari capaian hasil PISA bahwa pada kemampuan literasi matematika siswa tahun 2000 menempati peringkat 39 dari 41 negara, peringkat 38 dati 40 negara di tahun 2003, peringkat 61 dari 65 negara di tahun 2009, peringkat 64 dari 65 
negara di tahun 2012, sementara tahun 2015 Indonesia menempati peringkat 63 dari 70 negara yang mengikuti program PISA (Nahdi, 2019). Sejalan dengan itu, dapat diketahui bahwa hasil capaian PISA pada kemampuan siswa Indonesia dalam literasi matematika dikatakan kurang membanggakan dibandingkan dengan negara lain. Rata-rata kemampuan literasi yang dimiliki siswa hanya mencapai level 1 dan level 3 (Hidayat et al., 2019).

Kondisi serupa terjadi pada siswa SMP Terpadu Al Minhaj Kabupaten Batang pada kemampuan literasi matematika yang masih tergolong rendah. Hal itu didukung dari data hasil pertemuan MGMP dalam rangka membahas hasil simulasi AKM siswa kelas VIII di Kabupaten Batang tahun 2020 dilanjutkan dengan wawancara pada beberapa guru matematika MGMP Batang secara acak. Rata-rata hasil kemampuan pemecahan masalah pada domain aljabar kelas VIII di SMP N 3 Subah adalah 46,5 (Wawancara dengan Ning Cristina), rata-rata hasil kemampuan pemecahan masalah pada domain statistik kelas VIII di SMP N 2 Warungasem hanya 55 (Wawancara dengan Anggi Astuti), rata-rata kemampuan pemecahan masalah pada domain bilangan hanya 54 (Wawancara dengan Milawati). Adapun hasil kemampuan literasi numerasi siswa hasil simulasi AKM di SMP Terpadu Al Minhaj dapat dilihat pada tabel di bawah ini.

Tabel 1. Hasil Simulasi AKM Tahun 2020

\begin{tabular}{|c|l|c|c|}
\hline No & \multicolumn{1}{|c|}{ Konten } & Jumlah Siswa & Rata-Rata \\
\hline 1 & Bilangan & 5 & $20 \%$ \\
\hline 2 & Pengukuran dan geometri & 5 & $29 \%$ \\
\hline 3 & Data dan uncertainty & 5 & $42 \%$ \\
\hline 4 & Aljabar & 5 & $24 \%$ \\
\hline
\end{tabular}

Berdasarkan tabel 1 terlihat sangat jelas mengenai kemampuan literasi matematika di SMP Terpadu Al Minhaj belum bisa mencapai nilai minimal yang ditetapkan oleh MGMP yaitu minimal $50 \%$ harus mampu menjawab benar pada tiap konten yang ada pada soal. Berdasarkan analisis di dapat bahwa mayoritas siswa belum mampu untuk mengidentifikasi masalah, menentukan langkah yang tepat, serta menentukan kesimpulan yang tepat. Siswa masih kesulitan dalam membuat model matematika dari masalah yang disajikan pada soal. Siswa juga kurang terampil dalam menyelesaikan masalah sesuai dengan model matematika yang telah disusun. Hal ini menunjukkan bahwa kemampuan siswa dalam memodelkan dan menafsirkan matematika, mengidentifikasi masalah, secara matematik dari suatu masalah masih rendah. Berdasarkan hasil tersebut, bahwa kemampuan siswa untuk mengidentifikasi dan menuliskan masalah, kemampuan dalam mencapai solusi, 
menyimpulkan hasil matematika, menggunakan pemahaman konteks untuk menyelesaikan masalah, menggunakan representasi untuk memecahkan masalah merupakan komponen dari indikator kemampuan literasi matematika yang masih rendah, sehingga dapat dikatakan bahwa kemampuan literasi siswa SMP Terpadu Al Minhaj masih tergolong rendah.

Fenomena rendahnya capaian hasil belajar siswa pada kemampuan literasi matematika menyebabkan rendahnya capaian hasil belajar siswa pada materi yang telah dipelajari. Oleh sebab itu, kegiatan belajar harus dilakukan guru untuk membantu siswa dalam meningkatkan kemampuan literasi matematika yang baik (Madyaratri et al., 2020). Menurut (Masjaya \& Wardono, 2018) pembelajaran matematika terhadap siswa harus dirancang sedemikian rupa untuk memberikan peluang yang cukup kepada siswa untuk melatih, mengembangkan, dan meningkatkan kemampuan literasi matematika sebagai bagian penting dalam peningkatan hasil capaian pada survei yang akan datang. Kurikulum 2013 menyarankan kepada guru untuk menggunakan beberapa pendekatan maupun strategi pembelajaran yang mengacu ke dalam proses pemecahan masalah secara mandiri. Salah satu alternatif inovasi pembelajaran yang dapat digunakan guru adalah dengan menerapkan model pembelajaran berbasis masalah (Problem Based Learning).

Problem Based Learning (PBL) merupakan sebuah pendekatan pembelajaran yang menggunakan masalah dalam kehidupan sehari-hari sebagai suatu konteks bagi siswa untuk dapat belajar cara berpikir kritis dan keterampilan pemecahan masalah, serta untuk memperoleh konsep dari materi pelajaran (Anwar \& Jurotun, 2019). Sebagaimana Barrows (Madyaratri et al., 2020) mengungkapkan bahwa PBL merupakan suatu model pembelajaran yang dihasilkan dari proses bekerjasama menuju pemecahan masalah, di mana masalah diberikan kepada siswa pada awal proses pembelajaran sehingga siswa selalu aktif menggunakan pengetahuannya dan guru hanya sebagai fasilitator. Hal senada diungkapkan oleh (Indah et al., 2016) dan (Pamungkas et a l., 2019 ) bahwa secara umum siswa yang telah mengikuti pembelajaran dengan menggunakan PBL menunjukkan capaian hasil belajar yang lebih baik dalam kemampuan literasi matematika jika dibandingkan dengan siswa yang belajar secara konvensional.

Berdasarkan uraian di atas, maka dilakukan sebuah kajian studi literature yang bertujuan untuk mengkaji lebih mendalam mengenai kemampuan literasi matematika melalui penerapan model pembelajaran Problem Based Learning (PBL).

\section{METODE}

Penelitian ini menggunakan metode SLR (Systematic Literature Review). Systematic literature review atau tinjaun pustaka sistematis merupakan metode yang digunakan untuk menentukan, 
mengevaluasi, dan menginterpretasikan semua temuan masalah riset dalam menjawab pertanyaan yang sudah ditentukan (Hidayat et al., 2019). Dengan metode penelitian ini penulis melakukan review pada jurnal-jurnal ataupun artikel dengan mengikuti langkah-langkah yang telah ditetapkan (Triandini et al., 2019). Dalam menyelesaikan penelitian ini, penulis mengumpulkan berbagai artikel ataupun jurnal pada database Google Schoolar dan jurnal terakreditasi sinta.

Berdasarkan dari langkah-langkah prosedur penelitian di atas, maka penulis melakukan pencarian artikel penelitian yang relevan berkaitan dengan penelitian yang dilakukan, yakni model pembelajaran PBL untuk meningkatkan kemampuan literasi matematika siswa. Pengumpulan data dilakukan dengan cara mendokumentasikan semua artikel dan jurnal yang relevan dengan penelitian ini. Artikel yang digunakan pada penelitian ini sejumlah 20 yang dipilih dengan penelitian serupa kemudian artikel di analisis dan dirangkum. Hasil penelitian kemudian dijadikan ke dalam satu pembahasan yang utuh.

\section{HASIL DAN PEMBAHASAN}

Berdasarkan analisis artikel menunjukkan bahwa model pembelajaran Problem Based Learning (PBL) mempunyai keterkaitan dengan pencapaian kemampuan literasi matematika. Berdasarkan hasil kajian beberapa artikel dan jurnal penelitian menunjukkan bahwa model pembelajaran Problem Based Learning dapat mempengaruhi dan meningkatkan kemampuan literasi matematika baik di tingkat satuan pendidikan SMP, SMA, maupun perguruan tinggi. Hal tersebut dijelaskan dalam uraian pembahasan masing-masing artikel yang telah di analisis.

Kemampuan literasi matematika sangat dibutuhkan oleh semua orang yang hidup di zaman sekarang ini untuk menghadapi berbagai permasalahan yang muncul. Sebagaimana (Fitriono \& Artikel, 2015) dan (Saputro \& Murtiyasa, 2018) menyatakan bahwa alasan pentingnya kemampuan literasi adalah untuk membiasakan siswa dalam menyelesaikan masalah yang berkaitan dengan aplikasi matematika dalam kehidupan sehari-hari. (Marlina et al., 2020) juga menyatakan bahwa kemampuan literasi matematika merupakan salah satu kemampuan yang harus dimiliki seseorang tidak hanya siswa tetapi calon guru matematika juga penting. Sebagai calon guru kemampuan tersebut harus dimiliki untuk dapat menganalisis dan menggunakan matematika dalam berbagai bidang kehidupan. Kemampuan literasi matematika diartikan OECD (Wardono \& Mariani, 2018) sebagai kemampuan seseorang untuk merumuskan masalah, menerapkan, dan menganalisis penggunaan matematika dalam berbagai konteks, termasuk bernalar secara sistematis dan menggunakan konsep, prosedur, dan fakta untuk menggambarkan, menjelaskan atau memperkirakan fenomena/kejadian. Hal itu sesuai dengan standar isi yang terdapat dalam mata pelajaran matematika. 
Selaras dengan hal itu, berdasarkan penelitian dari (Indah et al., 2016) menyebutkan bahwa terdapat pengaruh positif antara PBL terhadap kemampuan literasi matematika siswa yang ditandai pada hasil pre test kelas VII E dengan perolehan rata-rata kemampuan literasi matematika yang meningkat, yaitu dari 43,70 dari nilai pre test sedangkan nilai rata-rata post test yaitu 51,35. Hal tersebut menunjukkan bahwa PBL berpengarih positif pada peningkatan kemampuan literasi matematika.

Penelitian yang dilakukan oleh (Sri et al., 2020) bahwa penerapan model pembelajaran PBL pada pembelajaran daring cukup baik, pada hasil observasi yang dilakukan dosen untuk mengelola pembelajaran secara keseluruhan siklus mencapai 3,60. Sedangkan pencapaian waktu ideal yang diperlukan untuk aktivitas mahasiswa dengan toleransi 5\% dan batas toleransi 3 dan 5 terpenuhi. Kemampuan literasi matematika mahasiswa setelah mengikuti pembelajaran menggunakan model pembelajaran PBL melalui daring sebesar 71,15 \% dengan kategori sedang, dan ketuntasan klasikal dari siklus I dan II sebesar 80,63\% dengan kategori telah memenuhi syarat klasikal. Peningkatan kemampuan literasi matematika mahasiswa menggunakan model PBL melalui daring mengalami peningkatan dari siklus I ke siklus II sebesar 20,72\%. Hal itu didukung dengan penelitian (Hidayat et al., 2019) bahwa hasil data kemampuan literasi matematika menunjukkan peningkatan yang signifikan dari 75,1 menjadi 85,00. Hal ini berarti kemampuan literasi matematika siswa mengalami peningkatan setelah diterapkan model PBL pada pembelajaran matematika. Hal itu juga senada dengan penelitian yang dilakukan oleh (Astuti, 2018) bahwa nilai rata-rata kemampuan literasi matematika siswa yang telah menggunakan model PBL sebesar 77,81 dengan standar deviasi 18,34 yang berarti bahwa rata-rata kemampuan literasi matematika siswa pada kelas eksperimen lebih baik dibandingan dengan kelas kontrol. Hal itu juga selaras dengan penelitian (Ramdhani, n.d.).

Hasil penelitian di atas juga didukung oleh penelitian (Paloloang et al., 2021) menggunakan meta-analisis dalam mengkaji pengaruh PBL terhadap peningkatan kemampuan literasi matematika. Dari hasil penelitiannya menunjukkan bahwa penerapan PBL memberikan pengaruh yang positif terhadap kemampuan literasi matematika siswa dibandingkan dengan pembelajaran seperti biasanya (konvensional).

Namun sebaliknya, pada hasil penelitian (Munir et al., 2020) menunjukkan bahwa kemampuan literasi matematika siswa dalam mengikuti pembelajaran PBL masih belum optimal, terutama bagi siswa yang memiliki kemampuan matematika awal yang rendah. Hal itu ditunjukkan adanya penelitian kualitatif deskriptif untuk mengidentifikasi kemampuan literasi matematika menggunakan model PBL siswa kelas X BDP 1 SMK Swadaya Semarang. Hasil pengamatan menunjukkan bahwa mayoritas siswa dalam memecahkan masalah matematika dengan bentuk soal non rutin dengan langkah merumuskan, menerapkan, dan menganalisis matematika dalam kehidupan sehari-hari masih 
rendah. Rendahnya kemampuan literasi matematika siswa akan menyebabkan kemampuan belajar siswa dalam memahamami materi matematika secara keseluruhan kurang. Untuk itu, perlunya pembiasaan siswa terhadap soal-soal yang mengacu pada indikator kemampuan literasi matematika. Oleh karena itu, direkomendasikan kepada satuan pendidikan untuk memasukkan kemampuan literasi matematika siswa ke dalam kurikulum pendidikan saat ini sehingga dapat mengembangkan dan meningkatkan kemampuan literasi matematika siswa di sekolah.

Telah banyak penelitian yang menunjukkan bahwa penggunaan model pembelajaran PBL dapat meningkatkan kemampuan literasi matematika siswa, seperti penelitiannya (S mp, 2014 ) bahwa model pembelajaran Problem Based Learning merupakan suatu model pembelajaran yang dirancang dan dikembangkan untuk mengembangkan kemampuan peserta didik dalam memecahkan masalah yang kaitannnya dengan literasi matematika. Menurut (Smp, 2014) Problem Based Learning dapat digunakan untuk meningkatkan kemampuan literasi matematis dengan beberapa alas an, diantaranya 1) menyediakan masalah yang dihubungkan dengan kehidupan nyata, 2) mendorong siswa untuk dalam kegiatan pembelajaran, 3) mendorong penggunaan berbagai pendekatan pembelajaran, 4) memberi kesempatan siswa untuk mengaktualisasikan kemampuannya, 5) menjadikan pembelajaran menjadi kolaboratif, dan 6) membantu mencapai pendidikan yang berkualitas. Adapun keunggulan dari PBL menurut Sanjaya (Octaria et al., 2018) meliputi 1) dapat membantu siswa memahami isi pelajaran, 2) melatih siswa untuk memecahkan masalah yang menantang kemampuannya, 3) siswa menjadi aktif dalam pembelajaran, 4) membantu siswa membentuk pengetahuan untuk memecahkan masalah nyata, 5) membantu siswa bertanggung jawab dalam kelompoknya, 6) mendorong siswa untuk mengevaluas pengetahuan yang didapatkan, 7) siswa menjadi senang dalam pembelajaran, 8) dapat memberikan kesempatan kepada siswa untuk mengaplikasikan pengetahuan yang mereka miliki dalam dunianya nyata.

Sementara itu menurut (Aziz et al., 2016) bahwa PBL memiliki beberapa keunggulan diantaranya, yaitu 1) siswa terlibat aktif pada setiap kegiatan pembelajaran sehingga pengetahuannya dapat diserap dengan baik, 2) siswa berlatih untuk bekerja sama dengan siswa lain dalam satu kelas, dan 3) siswa dapat memperoleh penggetahuannya dari berbagai sumber informasi yang mereka dapatkan. Dari beberapa keunggulan tersebut menunjukkan bahwa model PBL cocok untuk meningkatkan dan mengembangkan kemampuan literasi matematika siswa.

Adapun tahapan-tahapan model pembelajaran PBL menurut Sari (Astuti, 2018) dibagi menjadi lima tahap. Tahap pertama yaitu fokus orientasi siswa terhadap masalah. Pada tahap ini siswa diberikan permasalahan yang berkaitan dengan materi pelajaran. Tahap kedua yaitu tahap mengorganisaikan siswa. Pada tahap ini, siswa mendefinisikan masalah yang ditemukan dalam 
diskusi bersama dengan kelompoknya. Tahap ketiga yaitu tahap membimbing penyelidikan individu maupun kelompok. Pada tahap ini, guru mendorong siswa untuk mengumpulkan berbagai informasi yang relevan sebanyak-banyaknya untuk mencapai pemecahan masalah. Tahap keempat, mengembangkan dan menyajikan hasil karya. Pada tahap ini, siswa menyajikan hasil diskusinya dalam memecahkan masalah dengan mempresentasikan di depan kelas. Tahap terakhir adalah menganalisis dan mengevaluasi proses pemecahan masalah. Bersama guru siswa mengevaluasi hasil diskusi yang telah dilakukan sebelumnya.

Adapun indikator- indikator literasi matematika OECD (Saputro \& Murtiyasa, 2018) adalah sebagai berikut:

a. Kemampuan komunikasi, menuliskan proses dalam mencapai solusi dan menyimpulkan hasil matematika.

b. Kemampuan matematika, menggunakan pemahaman konteks untuk menyelesaikan masalah

c. Kemampuan representasi, menghubungkan dan menggunakan berbagai macam bentu representasi saat menyelesaikan masalah

d. Kemampuan penalaran dan argumen, menjelaskan pkebenaran dalam menentukan proses dan prosedur yang digunakan untuk hasil atau solusi matematis

e. Kemampuan memilih strategi yang sesuai untuk memecahkan masalah, menggunakan strategi melalui berbagai prosedur yang mengarah pada solusi dan kesimpulan matematis.

f. Kemampuan mengunakan bahasa dan operasi simbolis, formal dan teknis, menggunakan bentuk formal berdasarkan desinisi dan aturan matematika

g. Kemampuan menggunakan alat-alat matematika, menggunakan alat-alat matematika untuk mengenali struktur matematika atau untuk menggambarkan hubungan matematis.

Namun ada penelitian lain oleh (Utomo et al., 2020) menggunakan dari hasil pengembangan PISA menjadi enam level kategori yang memiliki indikator berbeda-beda pada setiap levelnya. Semakin tinggi tingkatan yang mampu dicapai siswa maka semakin baik pula kemampuannya. Berikut penjelasan dari masing-masing level kemampuan (Utomo et al., 2020).

Tabel 2. Indikator Level Kemampuan Literasi Matematika Menurut PISA

\begin{tabular}{|l|l|}
\hline Level & Indikator Kemampuan Siswa \\
\hline 1 & $\begin{array}{l}\text { Siswa mampu menjawab pertanyaan sesuai dengan konteks yang dikenal, } \\
\text { mengumpulkan informasi yang sesuai (relevan), dan bertindak sesuai dengan } \\
\text { stimulus }\end{array}$ \\
\hline 2 & $\begin{array}{l}\text { Siswa mampu mengenali keadaan, menggunakan algoritma atau rumus yang dan } \\
\text { digunakan dan mampu menginterpretasikan }\end{array}$ \\
\hline
\end{tabular}




\begin{tabular}{|l|l|}
\hline 3 & $\begin{array}{l}\text { Siswa mampu menerapkan strategi pemecahan masalah dengan prosedure yang baik, } \\
\text { menerapkan dan mempersentasikan situasi }\end{array}$ \\
\hline 4 & $\begin{array}{l}\text { Siswa mampu bekerja secara efektif dalam situasi yang konkrit dan kompleks, } \\
\text { mempresentasikan suatu informasi yang berbeda-beda serta menghubungkan pada } \\
\text { dunia nyata }\end{array}$ \\
\hline 5 & $\begin{array}{l}\text { Siswa mampu bekerja pada situasi yang kompleks menggunakan model pemecahan } \\
\text { masalah yang rumit, memilih serta menerapkan strategi yang tepat }\end{array}$ \\
\hline 6 & $\begin{array}{l}\text { Siswa mampu menggunakan penalaran, membuat generalisasi, dan } \\
\text { mengkomunikasikan suatu penyelesaian masalah }\end{array}$ \\
\hline
\end{tabular}

Adapun penelitian yang dilakukan oleh (Dina et al., 2018) berkaitan dengan indikator kemampuan literasi matematika adalah sebagai berikut: (a) mengidentifikasi fakta-fakta secara sistematis, (b) merumuskan masalah secara sistematis, (c) menggunakan konsep matematika untuk pemecahan masalah, (d) melakukan perhitungan berdasarkan prosedur tertentu, (e) menarik kesimpulan dari masalah yang diamati. Sementara itu penelitian (Hidayat et al., 2019) mengungkapkan ada empat indikator kemampuan literasi matematika yaitu: 1) argumentasi matematis, 2) penalaran dan berpikir matematis, 3) komunikasi matematis, dan 4) merumuskan penyelesaian masalah. Adapun indikator dalam penelitian yang menjadi acuan pengembangan kemampuan literasi matematika yang meliputi 6 level pencapaian adalah sebagai berikut.

a. Level 1: siswa mampu menjawab pertanyaan sesuai dengan masalah yang diberikan, mengumpulkan informasi yang berkaitan dengan konteks masalah, dan bertindak sesuai dengan situasi.

b. Level 2: siswa mampu mengenali situasi, menggunakan rumus yang sesuai dan menginterpretasikannya

c. Level 3: siswa mampu menerapkan strategi penyelesaian masalah dengan langkah-langkah yang sesuai

d. Level 4: siswa mampu bekerja secara efektif dalam situasi yang konkrit dan kompleks serta menghubungkan dengan masalah nyata

e. Level 5: siswa mampu bekerja pada situasi yang kompleks untuk memecahkan masalah yang rumit dan mmilih serta menerapkan strategi yang tepat.

f. Level 6: menggunakan penalaran, membuat generalisasi, dan mengkomunikasikan penyelesaian masalah. 
Adapun hubungan PBL dengan kemampuan literasi matematika seperti yang dikemukakan oleh Putra (Indah et al., 2016), memaparkan sintaks PBL meliputi lima fase sebagai berikut.

a. Orientasi masalah. Pada fase ini seorang guru menjelaskan kompetensi yang hendak dicapai, memberikan motivasi kepada siswa untuk terlibat dalam aktivitas pemecahan masalah yang dipilih.

b. Mengorganisir siswa untuk belajar. Pada fase ini, guru membantu siswa mengorganisasikan tugas belajar yang berhubungan dengan masalah yang disajikan.

c. Membimbing individu maupun kelompok. Pada fase ini, guru mengarahkan siswa untuk mengumpulkan informasi yang sesuai eksperimen.

d. Mengembangkan dan menyajikan hasil karya. Pada fase ini, guru membantu siswa dalam merencanakan dan menyiapkan karya dan membantu mereka untuk berbagi tugas dengan temannya.

e. Menganalisis dan mengevaluasi proses pemecahan masalah. Pada fase ini, guru membantu siswa untuk melakukan refleksi ataaupun evaluasi terhadap penyelidikan yang dilakukan dan prosesproses yang mereka gunakan.

Dari langkah-langkah yang telah dikemukakan terlihat bahwa pembelajaran berbasis masalah secara umum telah mengakomodasi kebutuhan pembelajaran yang dapat mengembangkan kemampuan literasi matematika siswa. Studi kasus Pembelajaran Berbasis Masalah, meliputi 1) penyajian masalah, 2) menggerakkan inquiry, 3) langkah-langkah PBM yang meliputi analisis inisial, mengangkat isu-isu belajar, literasi kemandirian dan kolaborasi pemecahan masalah integrasi pengetahuan baru, penyajian solusi, dan evaluasi.

Sementara itu, menurut (Istiandaru et al., 2015) terdapat keterkaitan antara langkah- langkah yang menjadi karakter PBL dengan komponen-komponen literasi matematika dapat dilihat pada tabel di bawah ini.

Tabel 3. Keterkaitan PBL dengan Komponen Kemampuan Literasi Matematika

\begin{tabular}{|l|c|c|}
\hline No & $\begin{array}{c}\text { Karakteristik PBL } \\
\text { (Problem Based Learning) }\end{array}$ & $\begin{array}{c}\text { Komponen Kemampuan } \\
\text { Literasi Matematika }\end{array}$ \\
\hline 1 & Orientasi siswa terhadap masalah & Memahami masalah \\
\hline 2 & $\begin{array}{c}\text { Mengorganisasi siswa untuk } \\
\text { berkolaborasi }\end{array}$ & $\begin{array}{c}\text { Memahami masalah } \\
\text { Menetapkan model }\end{array}$ \\
\hline 3 & $\begin{array}{c}\text { Membimbing pengalaman } \\
\text { individu/kelompok }\end{array}$ & $\begin{array}{c}\text { Menetapkan model } \\
\text { Menggunakan matematika }\end{array}$ \\
\hline
\end{tabular}




\begin{tabular}{|l|c|c|}
\hline 4 & $\begin{array}{c}\text { Mengembangkan dan menyajikan hasil } \\
\text { karya dikusi }\end{array}$ & $\begin{array}{c}\text { Menggunakan matematika } \\
\text { Menjelaskan solusi }\end{array}$ \\
\hline 5 & $\begin{array}{c}\text { Menafsirkan dan mengevaluasi proses } \\
\text { penyelesaian masalah }\end{array}$ & Menjelaskan solusi \\
\hline
\end{tabular}

\section{KESIMPULAN}

Berdasarkan hasil kajian beberapa literature di atas maka dapat ditarik kesimpulan bahwa PBL dapat berpengaruh positif dan signifikan untuk meningkatkan kemampuan literasi matematika siswa. Sementara itu keunggulan PBL yaitu 1) siswa dapat memahami isi pelajaran dengan mudah, 2) menemukan pengetahuan baru bagi siswa karena guru memberikan pemecahan masalah yang menantang kemampuan siswa, 3) siswa aktif dalam pembelajaran, 4) membantu siswa untuk memahami masalah dalam kehidupan nyata, 5) membantu siswa untuk mengembangkan pengetahuan barunya dan bertanggung jawab dalam kelompok, 6) dapat melakukan evaluasi diri, 7) lebih menyenangkan dan disukai siswa, 8) memberikan kesempatan kepada siswa untuk mengaplikasikan pengetahuan yang mereka miliki pada kehidupan nyata.

Adapun indikator yang menjadi bahan acuan dalam mengembangkan kemampuan literasi matematika melipti kemampuan komunikasi, kemampuan matematisasi, kemampuan representasi, kemampuan penalaran dan argumen, kemampuan memilih strategi untuk memecahkan masalah, kemampuan menggunakan Bahasa dan operasi simbolis, formal dan teknis. Pada kemampuan menggunakan alat-alat matematika terdiri dari 6 level. Level 1: menjawab pertanyaan sesuai materi yang dipelajari, mengumpulkan informasi yang relevan, dan bertindak sesuai dengan stimulus yang diberikan guru. Level 2: mengenali situasi, menggunakan algoritma atau rumus, dan menginterpretasikan. Level 3: menggunakan strategi pemecahan masalah dengan prosedur yang tepat. Level 4: bekerja secara efektif dalam situasi yang konkrit dan kompleks serta menghubungkan dengan dunia nyata. Level 5: bekerja untuk memecahkan masalah yang rumit dan memilih serta menerapkan suatu strategi. Level 6: menggunakan penalaran, membuat generalisasi, dan mengkomunikasikan suatu penyelesaian masalah.

Adapun keterkaitan antara langkah-langkah PBL dengan literasi matematika adalah pada tahap orientasi masalah terkait dengan memahami dan merumuskan masalah, pada tahap mengorganisasi siswa untuk berkolaborasi keterkaitan dengan memahami masalah dan menetapkan model, membimbing pengalaman individu/kelompok keterkaitan dengan menerapkan model dan menggunakan matematika, mengembangkan dan menyajikan hasil diskusi yang memiliki keterkaitan 
menggunakan matematika dan menjelaskan solusi, serta menganalisis dan mengevaluasi proses penyelesaian masalah berkaitan dengan menjelaskan solusi.

\section{DAFTAR PUSTAKA}

Anwar, K., \& Jurotun, J. (2019). Peningkatan Aktivitas dan Hasil Belajar Siswa SMA Pada Dimensi Tiga Melalui Model Pembelajaran PBL Berbantuan Alat Peraga. Kreano, Jurnal Matematika Kreatif-Inovatif, 10(1), 94-104. https://doi.org/10.15294/kreano.v10i1.19366

Astuti, P. (2018). Kemampuan Literasi Matematika dan Kemampuan Berpikir Tingkat Tinggi. 1, 263-268.

Aziz, A., Ahyan, S., \& Fauzi, L. M. (2016). IMPLEMENTASI MODEL PROBLEM BASED LEARNING ( PBL ) DALAM MENINGKATKAN KEMAMPUAN BERPIKIR KRITIS MAHASISWA MELALUI LESSON STUDY. 2(1), 83-91.

Dina, A., Puji, K., Studi, P., \& Purwokerto, U. M. (2018). Pengaruh Problem Based Learning Terhadap Kemampuan Literasi Matematis Siswa Kelas VII Di SMP Negeri 1 Bobotsari.4(32), $37-46$.

Fitriono, Y., \& Artikel, I. (2015). Unnes Journal of Mathematics Education Research MODEL PBL DENGAN PENDEKATAN PMRI BERPENILAIAN SERUPA PISA UNTUK MENINGKATKAN KEMAMPUAN LITERASI MATEMATIKA SISWA Abstrak. 4(1), 56-65.

Hidayat, R., Rahmatudin, J., \& Sriwahyuni, A. (2019). Kontribusi Model Pembelajaran Problem Based Learning Terhadap Kemampuan Literasi Matematis Siswa SMP. Didactical Mathematics, 1(2), 32-40. https://doi.org/10.31949/dmj.v1i2.1499

Humsona, R., \& Yuliani, S. (2018). 21 st centuries skill implication on educational system. https://doi.org/10.1088/1757-899X/296/1/012036

Indah, N., Mania, S., \& Learning, P. B. (2016). JURNAL MATEMATIKA DAN PEMBELAJARAN (M a P a n) VOL. 4 NO. 2, DESEMBER 2016. 4(2), 198-210.

Istiandaru, A., Istihapsari, V., Wardono, \& Mulyono. (2015). Problem Based Learning (PBL) dengan Pendekatan Realistik-Saintifik dan Asesmen PISA untuk Meningkatkan Kemampuan Literasi Matematika. Edumatica, 5(1), 1-11.

https://online-journal.unja.ac.id/index.php/edumatica/article/view/2670 
Madyaratri, D. Y., Wardono, \& Kartono. (2020). Mathematics Literacy Skill Seen from Learning Style in Discovery Learning Model with Realistic Approach Assisted by Schoology. Unnes Journal of Mathematics Education Research, 11(1).

Marlina, M., Nasrullah, A., Mahuda, I., \& Junedi, B. (2020). IMPLEMENTASI PROBLEM BASED LEARNING ( PBL ) UNTUK MENDUKUNG KEMAMPUAN LITERASI MATEMATIS. 13.

Masjaya, \& Wardono. (2018). Pentingnya Kemampuan Literasi Matematika untuk Menumbuhkan Kemampuan Koneksi Matematika dalam Meningatkan SDM. PRISMA, Prosiding Seminar Nasional Matematika, 1, 568-574.

Munir, M., Asikin, M., \& Junaedi, I. (2020). Kemampuan Literasi Matematika pada Pembelajaran Problem Based Learning Kelas X SMK. 2019.

Nahdi, D. S. (2019). Keterampilan Matematika Di Abad 21. Jurnal Cakrawala Pendas, 5(2), 133140 .

Octaria, D., Fitri, E., \& Sari, P. (2018). PENINGKATAN SELF-EFFICACY MAHASISWA MELALUI PROBLEM BASED LEARNING ( PBL ) PADA MATA KULIAH PROGRAM LINIER. 4(1), 6679.

Ojose, B. (2011). Mathematics literacy: are we able to put the mathematics we learn into everyday use? Journal of Mathematics Education, 4(1), 89-100.

Paloloang, M. F. B., Juandi, D., Tamur, M., Paloloang, B., \& Adem, A. M. G. (2021). META ANALISIS: PENGARUH PROBLEM-BASED LEARNING TERHADAP KEMAMPUAN LITERASI MATEMATIS SISWA DI INDONESIA TUJUH TAHUN Universitas Pendidikan Indonesia , Bandung , Indonesia Universitas Katolik Indonesia Santu Paulus Ruteng , Indonesia Universitas Tadulako . January. https://doi.org/10.24127/ajpm.v9i4.3049

Pamungkas, M. D., Franita, Y., Studi, P., Matematika, P., \& Tidar, U. (2019). kemampuan literasi matematis siswa. 5(2), 75-80.

Ramdhani, S. (n.d.). PENERAPAN MODEL PROBLEM BASED LEARNING ( PBL ) UNTUK MENINGKATKAN KEMAMPUAN LITERASI MATEMATIS SISWA SMK. 1, 1-13.

Saputro, R., \& Murtiyasa, B. (2018). Analisis Kemampuan Literasi Matematika Siswa dalam Menyelesaikan Soal Tipe PISA 2015. Universitas Muhammadiyah Surakarta, 2011, 472-481.

Smp, S. S. S. (2014). Jurnal Riset Pendidikan Matematika, Volume 1, Nomor 1, Mei 2014. 1(1), 4857. 
Sri, A., Hutagaol, R., Sopia, N., Studi, P., \& Matematika, P. (2020). VOX EDUKASI : Jurnal Ilmiah Ilmu Pendidikan KEMAMPUAN LITERASI MATEMATIKA MAHASISWA DALAM MODEL. 11.

Stacey, K., \& Turner, R. (n.d.). Assessing Mathematical Literacy.

Triandini, E., Jayanatha, S., Indrawan, A., Putra, G. W., \& Iswara, B. (2019). Metode Systematic Literature Review untuk Identifikasi Platform dan Metode Pengembangan Sistem Informasi di Indonesia. 1(2).

Utomo, M. F. W., Pujiastuti, H., \& Mutaqin, A. (2020). Analisis Kemampuan Literasi Matematika Ditinjau dari Gaya Kognitif Siswa. 11(2), 185-193.

Wardono, \& Mariani, S. (2018). The analysis of mathematics literacy on PMRI learning with media schoology of junior high school students. Journal of Physics: Conference Series, 983(1). https://doi.org/10.1088/1742-6596/983/1/012107

Wijaya, E. Y., Sudjimat, D. A., \& Nyoto, A. (2016). Transformasi pendidikan abad 21 sebagai tuntutan pengembangan sumber daya manusia di era global. Prosiding Seminar Nasional Pendidikan Matematika 2016, 1, 263-278. 